\title{
The Effect of Gas Industry Waste on Heavy Metals in Soil
}

\author{
Shodi Kholikulov ${ }^{1}$, Tursunboy Yakubov ${ }^{1 *}$, Isomiddin Bobobekov ${ }^{1}$ \\ 1 Samarkand State University, University blvd, 15, Samarkand, 140104, Uzbekisatan \\ * Corresponding author's email: pardaev78@mail.ru
}

\begin{abstract}
The article describes the effect of wastes on the amount of heavy metals in light serozem soils. The study examined the total amount of elements nickel, lead, zinc and copper. The results show that among the heavy metals studied, the highest amount of copper is at a distance of $500 \mathrm{~m}(55 \mathrm{mg} / \mathrm{kg})$ in the western direction of the Shurtan gas chemical complex, the maximum amount of total zinc is $98 \mathrm{mg} / \mathrm{kg}$ in the western direction at $1000 \mathrm{~m}$ and $1250 \mathrm{~m}$ in the northwest, at a distance of $1250 \mathrm{~m}$, the maximum amount was $1250 \mathrm{~m}$ in the north-west direction ( $202 \mathrm{mg} / \mathrm{kg}$ of soil) and the maximum amount of the nickel was $257 \mathrm{mg} / \mathrm{kg}$ of soil at a distance of $1850 \mathrm{~m}$ in the north-west direction. These numbers are several times higher than the background index and allowable norms of the studied elements. The maximum amount of the element lead is 8-9 times its allowable level, and nickel is more than 3 times. Pollution was mainly recorded on the southern, southeastern, and southeastern sides of the complex.
\end{abstract}

Keywords: wastes, heavy metals, gas chemical complex, soil pollution.

\section{INTRODUCTION}

One of the urgent tasks facing humanity is the efficient and rational use of available natural resources and the conservation and improvement of the ecological state of the natural environment. Soil protection plays a special role in maintaining the ecological condition of the environment. De-facto that humanity receives the food production it needs for itself, mainly at the plants that grown in the soil, herein, its importance becomes clear. It is not limited to food production, the cultivation of raw materials for industry, because the ecological role of soil in the biogeocenosis and biosphere is incomparable.

Currently, soil contamination with various harmful chemicals is becoming more common. This is mainly due to the irrational use of various chemical fertilizers and pesticides used in nuclear power plants, oil and gas production and processing enterprises, vehicles, railways, air transport, agriculture. As a result, the contamination of soils, which are one of the main components of the biosphere, with various harmful chemical compounds and elements, especially by heavy metals, is becoming more common.
Under the influence of various factors, heavy metals falling into the soil are added to biochemical flows and disturb the environmental sustainability of natural systems. Soil content, its physicochemical and microbiological properties change significantly negatively. As a result, it has a negative impact on living organisms and their ecological environment, including soil biogeocenoses. The most hazardous heavy metals for such the environment are mercury, lead, cadmium, arsenic. The study of changes in their distribution and quantity is important in improving soil properties and ecological condition.

It is known that heavy metals accumulate more in the soil than in other parts of the biosphere and have a negative impact on the ecosystem in the soilplant-animal-human system. Therefore, it is important to scientifically study the toxic effects of heavy metals and protect the ecosystem. An increase in the concentration of heavy metals in the soil has a negative impact on plant growth, development and productivity. Because they are protoplasmic poisons. Their toxicity increases with the increasing atomic mass of the elements. Therefore, the study of the 
amount of heavy metals in soils and the impact of various factors on it is a topical issue.

The development of industries and transport around the world, the man-made degradation of soils is the main reason. Several scientific studies are being conducted to study the contamination of soils with heavy metals, their harmful effects on soil properties, groundwater and surface water, plants, animals and the human environment.

In particular, the distribution of heavy metals in grassy podzol and black soils in relation to the level of man-made pollution was studied, and it was noted that cations of copper and lead elements inhibit the strong absorption of zinc and cadmium in the soil, which themselves are strongly absorbed $[9,10]$.

In the soils distributed around the copper processing plant in the Middle Urals (Russia), $\mathrm{Cu} 1375.0 \mathrm{mg} / \mathrm{kg}, \mathrm{Zn} 400 \mathrm{mg} / \mathrm{kg}, \mathrm{Cd} 4.0 \mathrm{mg} / \mathrm{kg}$, $\mathrm{Pb} 215 \mathrm{mg} / \mathrm{kg}$, and in the Southern Urals Cu 45.0 $\mathrm{mg} / \mathrm{kg}$, Zn 196 mg/kg, Cd $1.7 \mathrm{mg} / \mathrm{kg}$ were determined [8]. The presence of heavy metals (vanadium and nickel) in the waste from the combustion of gas industry torches has been noted [11].

Studying the ecological condition of the soils around the Ulyanovsk cement plant in the Russian Federation $[5,6]$, it was noted that the total zinc content ranged from 20.8 to $35.2 \mathrm{mg} / \mathrm{kg}$. It was observed that the accumulation of zinc in the soil has a negative effect on soil formation processes, reduces its biological activity, as well as affects its physical and physicochemical composition.

It was studied that the soil cover of recreational areas in the city of Vladimir is damaged by heavy metals such as lead, zinc, manganese, cobalt, chromium, nickel. In the Central Park of the city, in the top $0-10 \mathrm{~cm}$ layer of soil, lead $67.2 \mathrm{mg} / \mathrm{kg}$, zinc $130.0 \mathrm{mg} / \mathrm{kg}$, manganese 1311 $\mathrm{mg} / \mathrm{kg}$, cobalt $14.7 \mathrm{mg} / \mathrm{kg}$, chromium 94,2 mg/kg, nickel was found to be up to $43.1 \mathrm{mg} / \mathrm{kg}$ [4].

Studies in the soils of Cherdaklin district of Ulyanovsk region (Russia) show that in 10 years in the studied has been reported to increase following elements (from - to): $\mathrm{Zn}$ 20.6-30.6 $\mathrm{mg} / \mathrm{kg}$, Ni $12.1-23.5 \mathrm{mg} / \mathrm{kg}$; Cr $10-19.9 \mathrm{mg} / \mathrm{kg}$ each; the mobile forms of the elements studied were $\mathrm{Zn} 6.2-6.4 \mathrm{mg} / \mathrm{kg}$ and $\mathrm{Cu} 2.8-2.9 \mathrm{mg} / \mathrm{kg}$; Cr 0.7-3.6 mg/kg [2].

Many studies have been conducted to study the amount of heavy metals around industrial enterprises in the territory of the Republic of Uzbekistan. In particular, a study in Almalyk city found that heavy metals around industrial plants were several times higher than their Clark, such as zinc 314 times and lead 300 times higher. It has been reported that the amount of heavy metals decreases with distance from enterprises [1].

The total lead content in the ore of the Almalyk deposits was $160-280 \mathrm{mg} / \mathrm{kg}$, cadmium $14.8 \mathrm{mg} /$ $\mathrm{kg}$, fluorine $180-230 \mathrm{mg} / \mathrm{kg}$, copper $90-110 \mathrm{mg} /$ $\mathrm{kg}$, and zinc $170-270 \mathrm{mg} / \mathrm{kg}$. The total amount of lead in the waste around the Navoi Mining and Metallurgical Complex will increase to $60 \mathrm{mg} /$ $\mathrm{kg}$. In the light serozem, serozem-meadow and meadow soils around these enterprises, lead was $40 \mathrm{mg} / \mathrm{kg}$, zinc $30 \mathrm{mg} / \mathrm{kg}$, copper $30 \mathrm{mg} / \mathrm{kg}$, and fluorine $40-60 \mathrm{mg} / \mathrm{kg}$ [17].

The amount of lead in the heavy traffics in Tashkent is $100-200 \mathrm{mg} / \mathrm{kg}$, in the soils around the aircraft plant is $250-300 \mathrm{mg} / \mathrm{kg}$, and in the soils of industrial enterprises in the Karakamysh region is $300-350 \mathrm{mg} / \mathrm{kg}$ [18].

The amount of heavy metals in the coarsegrained fractions of the soil around the Almalyk Mining and Metallurgical Complex were $\mathrm{Cu}$ 4875 mg/kg; Zn 54800 mg/kg; Pb 16300 mg/kg; $\mathrm{Cd} 561 \mathrm{mg} / \mathrm{kg}$. As we move away from the source of pollution, the amount of heavy metals in the coarse-grained and very fine-grained fractions of the contaminated soils equalizes, and then the amount of heavy metals increases gradually in the very fine-grained fraction [22].

Experiments on heavy metal contamination in the soils of Syrdarya, Jizzakh and Tashkent regions $[13,14,15]$ show that in the irrigated meadow and newly irrigated meadow soils of Jizzakh region, nickel decreases along with the soil profile towards the parent rock. In the tillage layer of the soil, its content is $14-84 \mathrm{mg} / \mathrm{kg}$, and the amount of cadmium is $0.26-1.85 \mathrm{mg} / \mathrm{kg}$. Some soils of Syrdarya region are contaminated with lead, the amount of which is $120-420 \mathrm{mg} / \mathrm{kg}$. The soils of Bostanlyk district of Tashkent region are not contaminated with heavy metals. Irrigated soils of Samarkand region are slightly contaminated with heavy metals. The amount of lead in the top layer of irrigated meadow-alluvial soils in the region was $93 \mathrm{mg} / \mathrm{kg}$, while in the layer at a depth of 50-80 cm it was $68 \mathrm{mg} / \mathrm{kg}$. The amount of chromium was $63-93 \mathrm{mg} / \mathrm{kg}$ at a depth of 72 $\mathrm{cm}$ and $32-55 \mathrm{mg} / \mathrm{kg}$ at a depth of $130 \mathrm{~cm} \mathrm{[25].}$

In Pastdargom district of Samarkand region, studies have been conducted to improve the agro-ecological status of toxic substances (chromium and nickel) in irrigated typical serozem soils containing $0.85 \%$ and $1.75 \%$ humus 
using the phytoremediation method. According to the results of the experiment, in the control variant of low humus soils, chromium $16.2 \mathrm{mg} /$ $\mathrm{kg}$, nickel $17.3 \mathrm{mg} / \mathrm{kg}$, in the control variant of very humus soils chromium $22.0 \mathrm{mg} / \mathrm{kg}$, nickel $7.6 \mathrm{mg} / \mathrm{kg}$ formed [24].

The total manganese content in the ploughing layer of the typical serozem soils (Pastdargom district, 7/16 and Payarik district, sections 8/16) on the left and right banks of the 3rd terrace of the Zarafshan river fluctuates from 497.7 to 656.3 $\mathrm{mg} / \mathrm{kg}$. It is noted that its amount is related to the grain-size composition, $\mathrm{pH}$, parent material and the amount of humus of soil $[12,16]$.

The waste of the Samarkand Chemical Complex, one of the sources of heavy metal pollution of the irrigated soils of the Zarafshan oasis, has been studied by heavy metal pollution of typical serozem soils in the region $[20,21,26]$. It is noted that the area around the chemical plant is contaminated with copper, zinc, lead, arsenic, cobalt elements in the radius of 1500-2000 meters, as well as in the western and north-western directions in the wind direction. In the top $0-30 \mathrm{~cm}$ layer of soil, the maximum total amount of heavy metals studied: copper $1240 \mathrm{mg} / \mathrm{kg}$ (250 meters west of the plant), zinc $1450 \mathrm{mg} / \mathrm{kg}$ (700 meters west), lead $526 \mathrm{mg}$ and arsenic $410 \mathrm{mg} / \mathrm{kg}$ (250 meters to the west), cobalt $550 \mathrm{mg} / \mathrm{kg}$ ( 750 meters to the northwest). Moving away from the complex, the amount of heavy metals decreases.

From the cited sources, it can be seen that the effect of gas industry wastes on the amount of heavy metals in soils is not almost investigated. Taking into account the above, in our research, we studied the effect of emissions into the environment as a result of the activities of the Shurtan gas chemical complex on the amount of heavy metals in light serozem soils in the region.

\section{MATERIAL AND METHODS}

The object of the study was light serozem soils distributed around the Shurtan gas chemical complex. The study examined the total amount of nickel, lead, zinc and copper elements in these soils. The observations of this study were conductes on the surroundings Shurtan gas chemical complex between 2018 and 2020 (Fig. 1).

Soil sampling for the experiment was carried out based on the method recommended by V.V. Kovalsky and A.D. Gololobov [7]. In total, 402 samples were taken by hand auger. To determine the total amount of heavy metals, the soil in the air-dry state is burned in the "wet" method using a mixture of perchlorate and sulfuric acid. After filtration, the extract was dried and the precipitate obtained was transferred to a decinormal solution of hydrochloric acid. The total amount of elements was then determined on the DFS- 8 spectrograph by evaporation at the lower electrode in the emission spectral analysis method [20]. Statistical analysis of the results of the experiment was carried out by the method of Dospekhov [3].

\section{RESULT AND DISCUSSION}

It is known that Kashkadarya region accounts for $88 \%$ of Uzbekistan's natural gas and $92 \%$ of oil. Therefore, in 2001, the Shurtangas chemical complex was built and put into operation in Guzar district of Kashkadarya region. The production capacity of the complex is 3.5 billion cubic meters of natural gas per/year. It allows the production of 125 thousand tons of polyethylene granules, 100 thousand tons of compressed gas, 100 thousand tons of gas condensate, 2.5 thousand

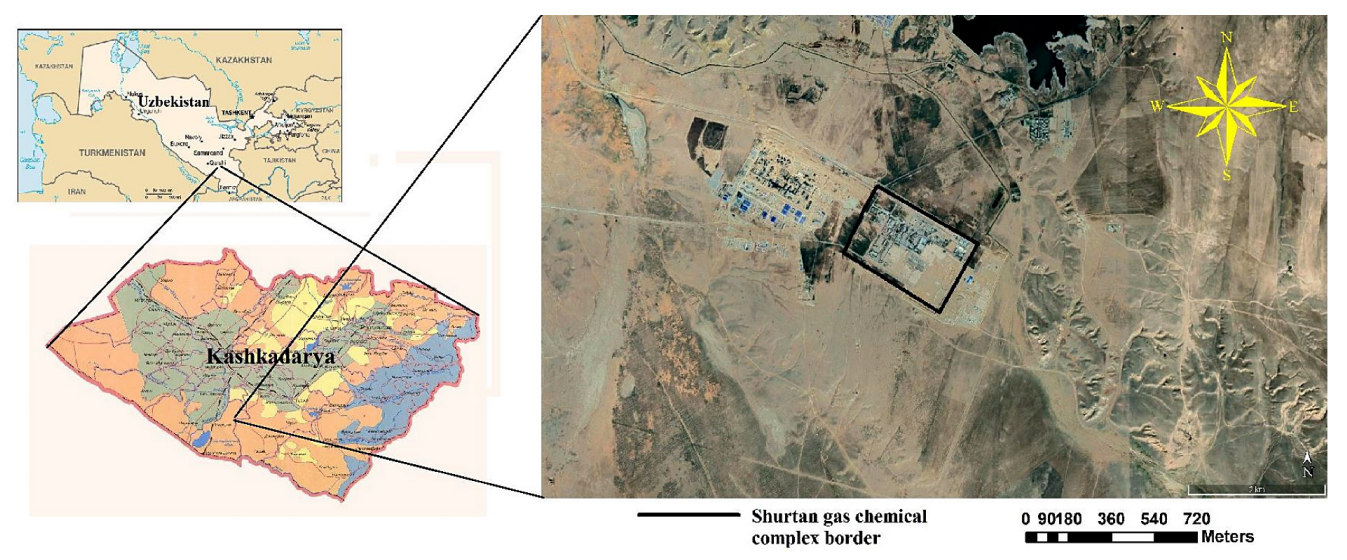

Figure 1. Geographical overview of the study area 


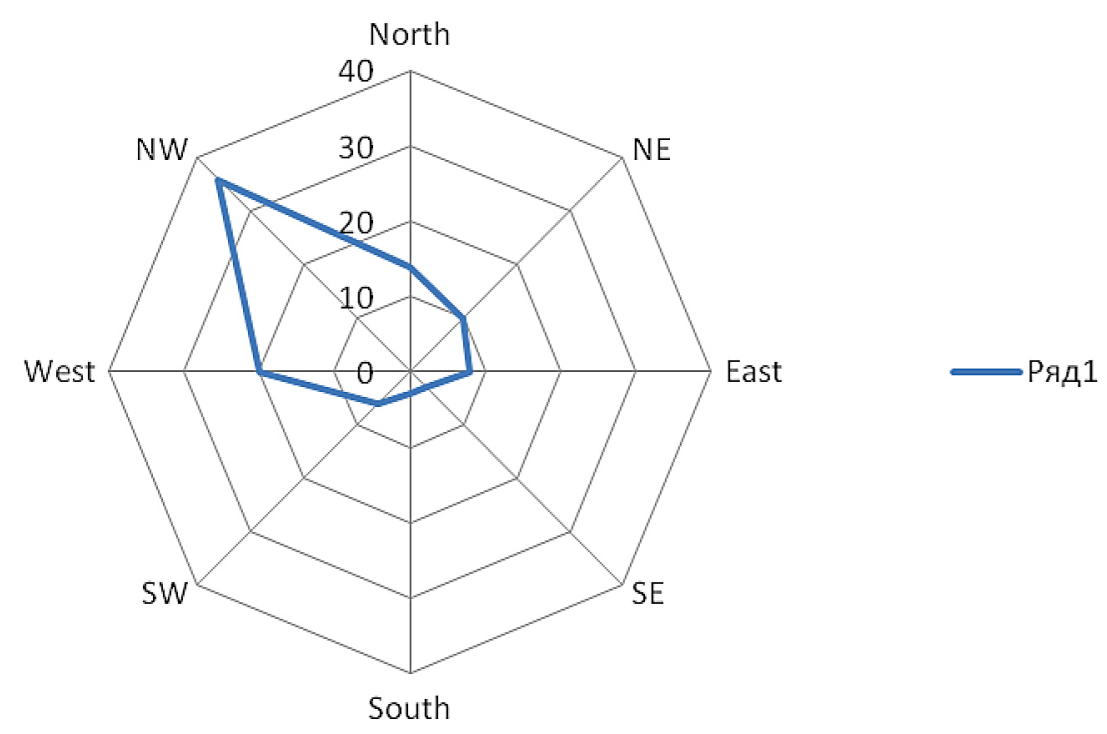

Figure 2. "Wind rose" of the area Shurtan gas chemical complex (\%)

tons of sulfur granules and 3.2 billion cubic meters of purified gas.

The climate of the study area is continental, the average annual air temperature is $16.4{ }^{\circ} \mathrm{C}$, and the coldest temperature is $-6{ }^{\circ} \mathrm{C}$. The average January temperature is $1.9^{\circ} \mathrm{C}$. The average temperature of summer is $+27^{\circ} \mathrm{C}$, the maximum temperature of $+30{ }^{\circ} \mathrm{C}$ is $+43{ }^{\circ} \mathrm{C}$, $+45{ }^{\circ} \mathrm{C}$. The hottest months are June-July. The wind regime has a specific effect on the climate of the region. Wind mode occurs under the influence of synoptic conditions. The wind regime is influenced by the specificity of the local relief. Figure 1 shows the "Wind rose" diagram, which shows the wind direction and average annual return in the region as follows (in percent) N-14, NE-10, E-8, SE- 3, S-3, SW-56, W-20, NW-36.

Figure 2 shows that the wind blows more from the northwest and west sides of the Shurtan gas chemical complex. If we look at the geological structure of the area, it is covered with deposits of eras such as Paleozoic, Mesozoic and Cenozoic. Palaeozoic deposits are located at a depth of 4-5 $\mathrm{m}$ according to geophysical data. The Mesozoic deposits are located above the Paleozoic deposits. Jurassic, Cretaceous, and Paleogene deposits are located at the base of Neogene deposits, and Quaternary deposits are common.

Shurtan gas chemical complex is located in the zone of light serozem soils. The parent rock of these soils consists of chalk deposits. It is characterized by the fact that groundwater is located at depth [23].
It was found that light serozem soils around the Shurtan gas chemical complex are mainly of light mechanical composition, the content of humus in the top layer of the soil is $0.6-0.7 \%$ and in some places $1.0-1.1 \%$. The amount of humus in the bottom layer from the grass layer decreases sharply. The amount of total nitrogen in the top layer exceeds $0.08-0.10 \%$, total phosphorus $0.07-0.11 \%$, and total potassium more than $2.0 \%$. The absorption capacity of the soil is not very large. The sum of the absorption capacity is $5-8 \mathrm{mg} / \mathrm{eqv}$ here of, $77-90 \%$ is related to calcium.

The studied ecosystem consisted of a formation of grasses, ephemeroids, and brownishbrown plants that grow thickly and form dense grasses to a depth of 5-8 cm. The growth period of plants belonging to the group of ephemerals is $30-45$ days. These plants dry out during the summer drought. In the zone mainly ephemeral plants with ephemeroids: Gagea stipitata, Ixiolirion tataricum, astragalus filicaulis, papaver pavoninum, Hordeum spontaneum, Salicornia herbacea, Alhagi sparsifolia, Tamarix hispida.

According to the study, the total amount of copper in one $\mathrm{kg}$ of soil in the area of the complex is $42 \mathrm{mg} / \mathrm{kg}$, zinc is $72 \mathrm{mg} / \mathrm{kg}$; lead is $142 \mathrm{mg} /$ $\mathrm{kg}$; the nickel was $197 \mathrm{mg} / \mathrm{kg}$ (Figs. 2-5). It was noted that the amount of elements studied varies in different directions as they move away from the complex. For example, copper is $42 \mathrm{mg} / \mathrm{kg}$ of soil at a distance of $100 \mathrm{~m}$ north of the complex; zinc is $72 \mathrm{mg} / \mathrm{kg}$; lead is $151 \mathrm{mg} / \mathrm{kg}$; if the nickel was found to be $184 \mathrm{mg} / \mathrm{kg}$ (Fig. 2), the 
amount of these elements in the western direction was $44 \mathrm{mg} / \mathrm{kg}$, respectively: $73 \mathrm{mg} / \mathrm{kg} ; 168 \mathrm{mg} /$ $\mathrm{kg} ; 197 \mathrm{mg} / \mathrm{kg}$, $44 \mathrm{mg} / \mathrm{kg}$ (Fig. 5). In the southern direction: $68 \mathrm{mg} / \mathrm{kg} ; 160 \mathrm{mg} / \mathrm{kg}$; $197 \mathrm{mg} / \mathrm{kg}$ (Fig. 4); to the east direction is respectively: $43 \mathrm{mg} /$ kg; $67 \mathrm{mg} / \mathrm{kg} ; 148 \mathrm{mg} / \mathrm{kg} ; 178 \mathrm{mg} / \mathrm{kg}$ (Fig. 3). As we moved away from the complex, the amount of heavy metals studied was observed to increase to a certain distance along the wind direction. The studied elements were mainly observed in the soils of the western, north-western and northern directions of the complex in comparison with other directions. This is mainly because of the wind in the area blows in these directions.

\section{North}

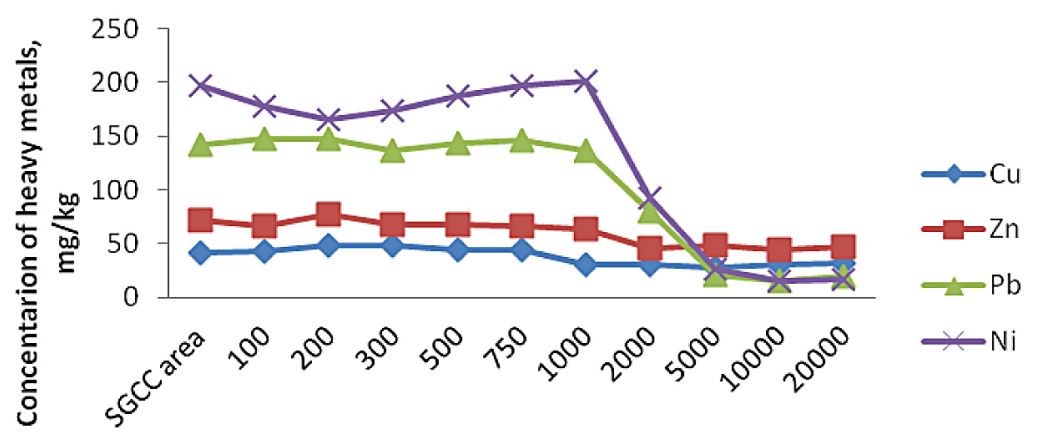

Distance, $m$

Figure 3. Total amount of heavy metals in the soil around the complex (North direction ), $\mathrm{mg} / \mathrm{kg}$ (in layers of $0-30 \mathrm{~cm}$ )

\section{East}

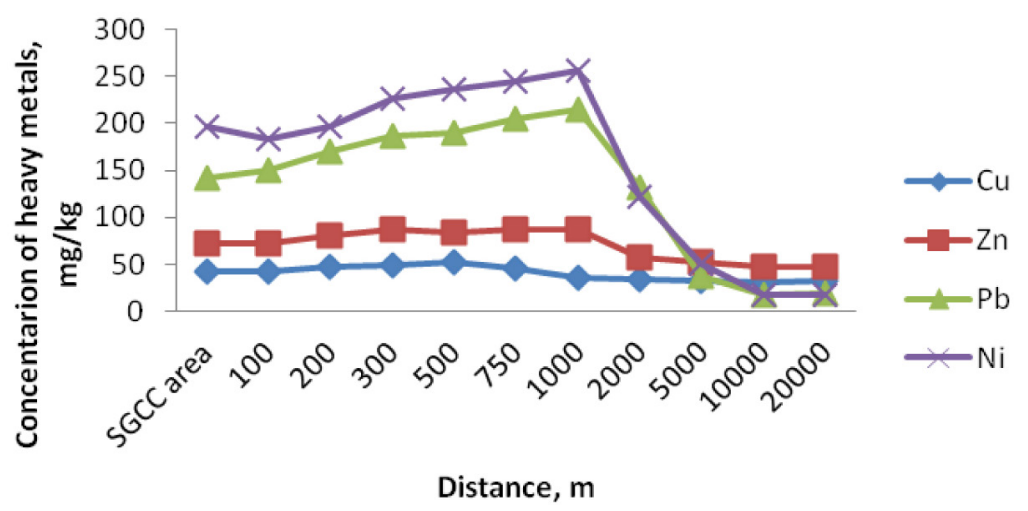

Figure 4. Total amount of heavy metals in the soil around the complex (East direction), $\mathrm{mg} / \mathrm{kg}$ (in layers of 0-30 cm)

\section{South}

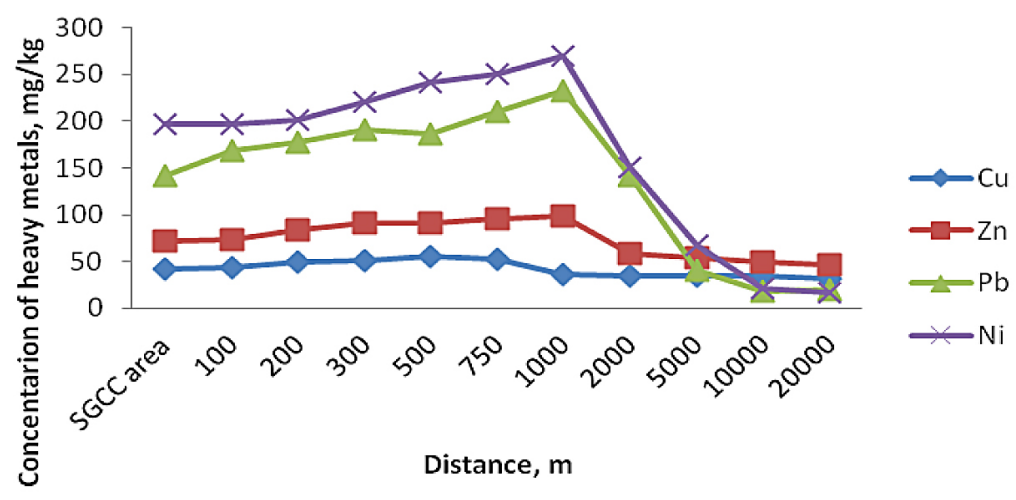

Figure 5. Total amount of heavy metals in the soil around the complex (South direction), $\mathrm{mg} / \mathrm{kg}$ (in layers of $0-30 \mathrm{~cm}$ ) 


\section{West}

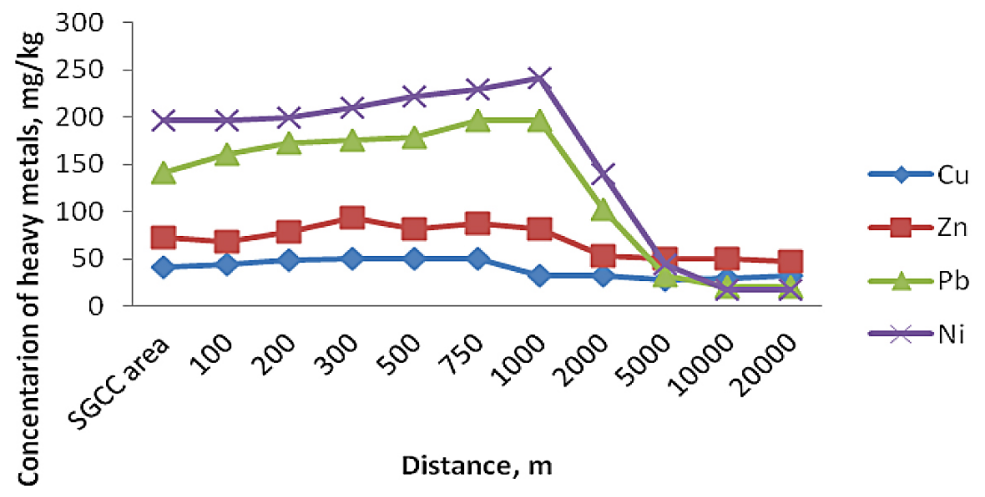

Figure 6. Total amount of heavy metals in the soil around the complex (West direction ), $\mathrm{mg} / \mathrm{kg}$ (in layers of 0-30 cm)

If we analyze the amount of heavy metals studied in the composition of light serozem soils distributed around the complex separately, we obtained the following results. That is, the highest amount of the copper element was determined in the southern direction of the complex at a distance of $500 \mathrm{~m}(55 \mathrm{mg} / \mathrm{kg})$ (Figs. 2-5). After this distance, the amount of copper is decreased. After a distance of 1000-1500 m from the complex, the amount of copper in all directions was equal to or close to the background. The amount of total copper in the background was $32 \mathrm{mg} / \mathrm{kg}$ of soil. That is, when we compare the maximum amount of this element $(55 \mathrm{mg} / \mathrm{kg}$ of soil $)$ with the background, we see that the amount of total copper around the complex is 1.7 times higher. The maximum allowable concentration (MAC) for total copper element is $55 \mathrm{mg} / \mathrm{kg}$ of soil, it can be concluded that the perimeter of the complex is unpolluted with the total form of copper.

In the light serozem soils pervasive around the complex, the total zinc was determined at 98 $\mathrm{mg} / \mathrm{kg} 1000 \mathrm{~m}$ south of the complex and 1250 $\mathrm{m}$ south-east. These values are almost 2.1 times higher than its background value $(47 \mathrm{mg} / \mathrm{kg})$. After this distance, the amount of zinc decreases again. After a distance of $2000 \mathrm{~m}$ from the Shurtangas chemical complex, the amount of zinc in all directions decreases sharply and almost approaches the background. Given that the maximum allowable concentration (MAC) set for this element is $100 \mathrm{mg} / \mathrm{kg}$ of soil, it can be concluded that the light serozem soils around the complex are not contaminated with total zinc either.

In the light serozem soils around the complex, the lead element was noted to be several times higher than the maximum allowable concentration (MAC) $(30 \mathrm{mg} / \mathrm{kg})$ and background value $(20 \mathrm{mg} / \mathrm{kg})$ of this element. The highest levels of lead were found in the study at a distance of $1000 \mathrm{~m}$ in the southern direction of the complex (232 $\mathrm{mg} / \mathrm{kg}$ of soil), $1250 \mathrm{~m}$ in the south-west $(240 \mathrm{mg} / \mathrm{kg}$ of soil) and $1500 \mathrm{~m}$ in the south-east ( $276 \mathrm{mg} / \mathrm{kg}$ of soil). These figures show that lead is $8-9$ times higher than MAC and 12-13 times higher than MAC.

In addition to the waste from the complex, the activity of vehicles moving in the area may have had a specific effect on the contamination of light serozem soils around the complex with lead. That is, the amount of lead is relatively high around the Karshi-Nuristan-Shurtan highway, located in the south-western direction of the complex.

As mentioned above, in the south-western direction of the complex at a distance of $1250 \mathrm{~m}$ (the amount of lead is $202 \mathrm{mg} / \mathrm{kg}$ of soil) is the around of this road. In other areas, a sharp decrease of lead element was observed after 1500$2000 \mathrm{~m}$, while in the south-eastern direction at a distance of $2500-3000 \mathrm{~m}$ it was observed that the amount of lead was more than $100 \mathrm{mg} / \mathrm{kg}$ of soil. In other directions, less than MAC after distances of 4000-5000 m, areas close to the background, in this direction the total lead content at these distances was recorded around $50-60 \mathrm{mg} /$ $\mathrm{kg}$, and after $6000 \mathrm{~m}$ approached the background $(20 \mathrm{mg} / \mathrm{kg})$. Hence, the distribution of total lead in the light serozem soils around the complex shows that it depends not only on the activity of the complex but also on the transport activity.

Our studies have shown that the soils around the complex are also contaminated with total nickel (Figs. 2-5). The highest amounts of the nickel element were observed mainly at a 
distance of $1000-1500 \mathrm{~m}$ around the complex and in the south, southwest, west and southeast directions, depending on the wind direction. The highest amounts of total nickel were recorded at $280 \mathrm{mg} / \mathrm{kg}$ of soil (1500 meters in the south) and $298 \mathrm{mg}$ (2100 meters in the south-east). These amounts are several times higher than the background amount of total nickel $(17 \mathrm{mg} / \mathrm{kg})$ and MAC $(85 \mathrm{mg} / \mathrm{kg})$. In the light-serozem soils at a distance of 2500-3000 $\mathrm{m}$ in the south-eastern direction from the complex, amounts of total nickel over MAC were detected.

The distribution of total nickel in the light serozem soils around the complex can be explained by the wind effect the spread of the wastes generated by the complex activities. To reduce the contamination of the soils of the study area with heavy metals, phytoremediation [31], biochar [32], enrichment of soils with organic matter, use of mineral fertilizers, including phosphorus fertilizers $[28,29,30]$ are recommended. In particular, high results were obtained by the combined use of organic and mineral fertilizers [21,27].

\section{CONCLUSION}

According to the study of the content of heavy metals in the irrigated light serozem soils around the Shurtangas chemical complex, the soils around the complex are mainly contaminated with lead and nickel elements. The maximum amount of the element lead is 8-9 times its allowable level, and nickel is more than 3 times. Pollution was mainly recorded on the southern, southeastern, and southeastern sides of the complex. The main reason for this is the spread of complex wastes in these directions under the influence of wind. Traffic may also have contributed to the spread of heavy metals in the soil.

\section{REFERENCES}

1. Arutyunyan S.S. The impact of copper smelting on the environment. The Republican Conference of Biogeochemistry of the Zarafshan Valley, Samarkand, 1997, 85-87.

2. Boltunova A.D., Smirnova S.V., Soltis V.V. 2017. Accumulation of heavy metals in soils under the influence of industrial production. Journal of Modern Problems of Science and Education, 4, 2017, 181184. http://www.science-education.ru/ru/article/ view? $\mathrm{id}=26637$.
3. Dospekhov B.A. Field experiment technique. M: Agropromizdat, 1985, pp. 351.

4. Zabelina O.N. Assessment of the ecological state of the soil of urban recreational territories on the basis of indicators of biological activity (for example, Vladimir). Vladimir, 2014, 59-69.

5. Kazakova N.A., Yakovleva I. Ecological state of soil cover in the zone of influence of cement production. The Chuvash State Pedagogical University of the Chuvash State Pedagogical University, 4(68), 2010, 71-74.

6. Kazakova N.A. 2014. Environmental assessment of the state of the soil and vegetation cover in the zone of technogenic pollution (on the example of the Ulyanovsk cement plant). Dissertation for the degree of candidate of biological sciences. Ulyanovsk, 2014, 66-68.

7. Kovalsky V.V., Gololobov A.D. Methods for the determination of trace elements in organs and tissues of animals, plants and soils. Moscow: Kolos, 1969, pp. 272.

8. Kovalchuk L.A., Stonkina O.A., Tarkhanova A.E. Heavy metals in the environment. Of the Middle Urals and their effect on the body. Journal of Ecology, 5, 2002, 358-361.

9. Ladonin D.V., Plyaskina O.V. Changes in the fractional composition of copper, zinc, cadmium and lead in some types of soils with element-wise pollution. Collection of articles of the Ivanovo State Agricultural Academy, Ivanovo, 4, 2001, 184-197.

10. Ladonin D.V. Compound of heavy metals in soils - problems and methods of study. Journal of Soil Science, 6, 2002, 682-692.

11. Orlov D.S. Ecology and protection of the biosphere in case of chemical pollution. Higher School, 2002, pp. 334.

12. Rozikova K.E., Xoshimov F.X., Sanakulov A.L. 2020. The amount of manganese in irrigated soils of Camarkand region, its accumulation and migration. Reports of the Academy of Sciences of the Republic of Uzbekistan, 1, 68-73.

13. Riskieva X.T., Riskiev R.R., Nasedjanov M., Mirsadikov M. The content of pollutants in irrigated soils and waters of the Hungry Steppe. Problems and tasks of increasing soil fertility of Mirzachul oasis. Collection of reports of the Republican scientific-practical conference, Guliston, UZB, April, 2003, 19-23.

14. Riskieva X.T. Toxicological conditions and ecological functions of the landscape. Proceedings of the 4th Congress of the Society of Soil Scientists and Agrochemists of Uzbekistan. Tashkent, 2005, 84-94.

15. Risqieva H.T., Mirsadiqov M. The amount of pollutants in irrigated soils. Irrigated soils of Syrdarya and Jizzakh regions. FAN, Tashkent, 12005, 179-241. 
16. Sanaqulov A. 2016. Distribution and accumulation of manganese (Mn) microelement in Zarafshan valley soils. Journal of Agroilm, 6(44), 2016, 63-64.

17. Tursunov D.X., Tursunov X.X., Azizov A.A. Contamination of soils and plants of the regions of Uzbekistan with heavy metals in industrial wastes. Bukhara, 2000, 67-68.

18. Tursunov X.X., Tursunov D.X. Determination of the level of contamination of Tashkent soils with heavy metals in industrial waste. Environmental problems in agriculture International scientificpractical conference, Bukhara, UZB, 2003, 71-75.

19. Vorobieva L.A., Glebova G.I., Gorshkova E.I., Grindel N.M., Zyrin N.G., Motuzova G.V., Obukhov A.I., Orlov D.S., Osipova N .N., Sokolova T.A. Physico-chemical methods of soil research. Moscow State University, 1980, pp. 382.

20. Kholikulov Sh. Heavy metals in the soil. Editor's Publishing, 2018, pp. 234.

21. Kholikulov Sh.T., Bobobekov I. The amount of heavy metals in typical gray soils and plants that are man-made contaminated irrigated", Scientificpractical conference dedicated to the 100th anniversary of the National University of Uzbekistan named after M. Ulugbek, Tashkent, Uzbekistan, April, 2019, 120-125

22. Shukurov N. Environmental impact of the mining and metallurgical industry. Journal of Ecology Bulletin, 3, 2001, 5-7.

23. Atlas of soil cover of the Republic of Uzbekistan. Tashkent, 2010, pp. 24.
24. Karimov X.N. 2014. Improving the agro-ecological condition of soils contaminated by phytomeremia, Journal of Biology of Uzbekistan, 6, 2014, 54-57.

25. Karimov X.N., Risqiyeva X.T. Man-made pollution of irrigated soils of Zarafshan oasis with heavy metals, Journal of Biology of Uzbekistan, 4, 2014, 51-54.

26. Kholikulov Sh., Bobobekov I. Anthropogenic pollution of irrigated serozem soils of Zarafshan valley. Journal of Environmetal radioecology and applied ecology, 10(4), 2004, 23-29.

27. Bobobekov I.N. The effect of organic and mineral fertilizers on the reduction of heavy metals in typical gray soils with anthropogenic contamination (On the example of soils around the Samarkand Chemical Plant). Synopsis of the dissertation for the degree of Candidate of Agricultural Sciences, Tashkent, 2006, pp. 22.

28. Alekseev Yu.V. Heavy metals in soils and plants. Leningrad, Agropromizdat, 1987, pp. 141.

29. Gupta D.K., Chatterjee S, Datta S., Veer V, Walther C. Role of phosphate fertilizers in heavy metal uptake and detoxification of toxic metals. Journal of Chemosphere, 108, 2014, 134-144.

30. Salama F. Influence of organic fertilizers on the mobility of heavy metals in soils and their entry into plants, Synopsis of dissertation candidate of biological sciences. Moscow, 1993, pp. 22.

31. Chibuike G.U., Obiora S.C. Heavy metal polluted soils: Effect on plants and bioremediation methods. Applied and Environmental Soil Science. doi: $10.1155 / 2014 / 752708$. 